\title{
ANALISIS EFEKTIVITAS PELAKSANAAN PROGRAM COMMUNITY DEVELOPMENT SEBAGAI BENTUK CORPORATE SOCIAL RENSPOSIBILITY OLEH PT. CHEVRON DI KABUPATEN GARUT
}

\author{
Oleh: \\ Rivani \\ Risna Resnawaty
}

\begin{abstract}
ABSTRAK
Penelitian ini dilakukan dengan tujuan utama untuk mengetahui sejauh mana efektivitas pelaksanaan program community development sebagai bentuk corporate social responsibility oleh PT. Chevron di Kabupaten Garut.

Metode penelitian yang digunakan adalah metode penelitian survey dengan jenis penelitian deskriptif analisis. Populasi penelitian ini adalah seluruh KK yang ada di Desa Padaawas, Kecamatan Pasirwangi, Kabupaten Garut, yang berjumlah 1133 orang KK. Sedangkan ukuran sampel berjumlah 43 orang KK, dengan teknik pengambilan sampel dengan cara proportionate random sampling. Pengumpulan data meliputi studi pustaka dan penelitian lapangan dengan cara observasi, wawancara, dan pengisian kuesioner. Teknis analisis data yang digunakan adalah analisis deskriptif dengan dukungan tabel frekuensi dan garis interval untuk intepretasi kategori.

Hasil dari perhitungan akumulasi jumlah skor dan garis interval didapat bahwa efektivitas pelaksanaan program community development oleh PT.Chevron berada pada kategori "tidak baik" dengan jumlah skor 1301. Hal ini menunjukkan bahwa pelaksanaan program ini belum efektif. Halhal yang masih kurang optimal dalam pelaksanaan program ini adalah fasilitasi kerja sama akses pada bidang ekonomi maupun sosial. Sedangkan Hal yang sudah efektif adalah pembangunan struktur infrastruktur berupa jalan, renovasi gedung, fasilitas air bersih, dsb.
\end{abstract}

\section{PENDAHULUAN}

\section{Latar Belakang Penelitian}

Persaingan usaha yang semakin tinggi, menuntut setiap perusahaan untuk mahir dalam menerapkan keunggulan strateginya guna mengoptimalkan laba. Konsep manajemen yang terkini membantu perusahaan dalam mengelola operasional perusahaan agar selalu berjalan efektif dan efisien. Tetapi untuk mencapai keuntungan yang berkesinambungan, saat ini perusahaan tidak bisa hanya memperhatikan kepentingan perusahaan saja, tetapi juga harus memperhatikan kepentingan para stakeholder lainnya, yakni pemerintah dan masyarakat setempat. Untuk itu maka perusahaan melakukan suatu program yang dinamakan sebagai pemberdayaan masyarakat atau sering dikatakan sebagai community development. Program ini pada dasarnya adalah suatu kegiatan perusahaan untuk perduli terhadap pengembangan wilayah sekitarnya yang didasarkan kebutuhan komuniti lokal, sebagai wujud tanggung jawab sosial perusahaan (corporate social responsibility). Hal ini menjadi perhatian perusahaan, bukan saja untuk menjaga berkesinambungannya laba, tetapi juga sudah merupakan komponen wajib 
dari penerapan standar manajemen mutu skala internasional.

Demikian juga PT. Chevron. Perusahaan multinasional ini bergerak di bidang pembangkit listrik tenaga panas bumi, dan salah satu proyeknya adalah membangun pembangkit listrik tenaga panas bumi (PLTP) di kawah darajat Kabupaten Garut. Hingga saat ini PT.Chevron sudah membangun tiga unit PLTP, yakni Darajat I, II, dan III. Potensi geotermal yang telah dimanfaatkan ketiga unit pembangkit itu mencapai 225 MW (megawatt). Bila dikonversi dalam bentuk uang, pendapatan PT.Chevron dari hasil penjualan listrik kepada PT.PLN dan Indonesia Power berkisar miliaran per tahun. Namun, kehadiran PT.Chevron belum menjadi stimulus pertumbuhan ekonomi rakyat di Garut. Padahal, perusahaan itu memiliki semacam tanggung jawab sosial membuat skema semacam redeployment center bagi rakyat, terutama di sekitar proyek. Memang selama ini, pemerintah kabupaten (pemkab) Garut selalu mendapat paparan tentang community development (CD) dengan sejumlah anggaran dana, namun hal tersebut tetap belum memberikan kontribusi yang nyata untuk pertumbuhan ekonomi masyarakat di sekitar. Berdasarkan wawancara dengan seorang pejabat pemkab Garut diketahui bahwa sebenarnya tuntutan ini sudah mulai muncul sejak tahun 2002 lalu, dan sudah sering terjadi pertemuan antara pemkab Garut dengan pihak PT.Chevron untuk membahas hal ini, tetapi sampai sekarang belum mencapai titik temu. Lalu pada penelitian awal di PT.Chevron, didapat juga data bahwa perusahaan tersebut telah berkontribusi dalam melaksanakan program Community Development (CD) di kabupaten Garut selama 10 tahun (dari tahun 1995 sampai dengan 2005) telah menghabiskan dana sebesar 1.341.453 US dollar, atau kurang lebih sekitar 10 miliar rupiah yang dialokasikan pada berbagai fokus kategori, diantaranya untuk kategori pendidikan, pengembangan ekonomi, kepedulian kesehatan, serta pembangunan infrastruktur. Untuk lebih spesifiknya, alokasi sejumlah anggaran tersebut, dapat dilihat pada tabel 1 tentang kontribusi program ini :

Tabel 1.

Kontribusi Program CD PT. Chevron tahun 1995 s/d 2005

\begin{tabular}{|c|c|}
\hline Tahun & $\begin{array}{c}\text { Jumlah Dana (US } \\
\text { Dollar) }\end{array}$ \\
\hline 1995 & 3.128 \\
\hline 1996 & 19.661 \\
\hline 1997 & 22.489 \\
\hline 1998 & 120.877 \\
\hline 1999 & 51.646 \\
\hline 2000 & 48.393 \\
\hline 2001 & 23.334 \\
\hline 2002 & 103.967 \\
\hline 2003 & 73.227 \\
\hline 2004 & 121.373 \\
\hline 2005 & 753.359 \\
\hline Jumlah & $\mathbf{1 . 3 4 1 . 4 5 3}$ \\
\hline
\end{tabular}

(sumber: olahan data PT.Chevron 2005)

Berdasarkan tabel diatas, dapat diketahui bahwa alokasi terbesar untuk program CD ini adalah pada tahun 2005, karena pada tahun ini banyak alokasi anggaran untuk pembangunan infarstruktur. Meskipun demikian, sejumlah alokasi dana program CD yang cukup besar ini, belumlah cukup untuk membangun citra yang bagus di mata masyarakat dan pemerintah kabupaten Garut. Peristiwa adanya pemblokiran karyawan PT.Chevron oleh masyarakat suatu desa di kecamatan pasirwangi kabupaten Garut, merupakan pertanda adanya "perang dingin" antara PT.Chevron dengan kecemburuan masyarakat desa sekitar lokasi perusahaan yang merasa tidak mendapat keuntungan dari perusahaan ekplorasi kekayaan daerahnya. Selain itu, peristiwa penolakan penandatanganan proyek perluasan dari PT.Chevron oleh pejabat bupati setempat pada masa menjabat tersebut, menjadi indikasi bahwa alokasi dana yang besar untuk program CD saja belumlah cukup untuk menunjukkan kebermanfaatan program tersebut bagi para stakeholders maupun perusahaan itu sendiri.

Dari fenomena tersebut, peneliti menganggap perlu untuk dilakukan penelitian dengan judul : "Analisis Efektivitas 
Pelaksanaan Program Community Development Sebagai Bentuk Corporate Social Rensposibility Oleh PT. Chevron Di Kabupaten Garut". Agar lebih terarah, peneliti juga membatasi masalah penelitian ini pada :

1. Bagaimana wujud dari pelaksanaan program community development oleh PT. Chevron.

2. Seberapa jauh tingkat efektivitas pelaksanaan program community development oleh PT. Chevron.

3. Hambatan apa saja dalam pelaksanaan program community development yang dihadapi oleh PT. Chevron.

4. Bagaimana cara mengatasi hambatanhambatan pelaksanaan program community development oleh PT. Chevron.

Tujuan dari penelitian ini adalah untuk mengetahui dan menganalisis lebih lanjut, mengenai perumusan masalah di atas. Sedangkan manfaat dari penelitian ini diharapkan dapat memberi kontribusi pada :

1. Manfaat bagi PT. Chevron : penelitian ini dapat dijadikan dasar untuk melaksanakan program community development yang lebih optimal.

2. Manfaat bagi masyarakat kabupaten Garut, khususnya di desa Padaawas kecamatan Pasirwangi : penelitian ini dapat menjadi sarana menyampaikan aspirasinya agar program community development yang dilaksanakan lebih sesuai dengan kebutuhan mereka.

3. Manfaat bagi pemerintah kabupaten Garut, khususnya Bappeda : penelitian ini dapat menjadi bahan informasi guna mendukung sinergitas rencana program pembangunan daerahnya dengan program community development yang dilakukan oleh perusahaan.

4. Manfaat bagi peneliti : penelitian ini dapat digunakan sebagai upaya pengembangan ilmu pengetahuan, khususnya untuk bidang kajian community development dan corporate social responsibility.

\section{Konsep Efektivitas Pelaksanaan Program Community Development \\ Efektivitas diartikan sebagai} pengukuran dalam arti tercapainya sasaran atau tujuan yang ditentukan sebelumnya. Kalau tujuan/sasaran itu tidak selesai sesuai dengan waktu yang telah ditetapkan, pekerjaan itu tidak efektif ." (Handayaningrat, 1988). Dari pengertian ini dapat disimpulkan bahwa efektivitas itu mengenai tercapainya tujuan yang telah ditetapkan sebelumnya. Sedangkan mengenai pengertian community development adalah kegiatan pembangunan komunitas yang dilakukan secara sistematis, terencana dan diarahkan untuk memperbesar akses komunitas guna mencapai kondisi sosial, ekonomi dan kualitas kehidupan yang lebih baik (Budimata, 2002). Definisi ini menyatakan bahwa tujuan dari community development yaitu peningkatan kualitas pada berbagai bidang kehidupan. Oleh karena itu untuk pengukuran efektivitas program community development, digunakan dimensidimensi community development yang menjadi tujuan yang akan dicapai pada proses pelaksanaannya, yaitu dimensi pembangunan manusia, sosial, ekonomi, politik, lingkungan hidup, dan kebudayaan (Jim Ife, 1997). Hal ini di dukung dimensi yang menjadi tujuan corporate social responsibility yakni peningkatan pada dimensi manusia, sosial, lingkungan hidup dan ekonomi, sebagai wujud tanggung jawab sosial perusahaan terhadap stakeholdernya. (Bambang Rudito, 2004).

\section{METODE PENELITIAN \\ Metode Penelitian}

Metode yang digunakan dalam penelitian ini adalah deskriptif analisis artinya menggambarkan dan mendeskripsikan fenomena yang ada saat penelitian ini dilaksanakan (Masri Singarimbun: 1989). Penelitian ini akan menggambarkan fenomena masalah pelaksanaan program community development yang dilaksanakan PT.Chevron di kabupaten Garut, dan menganalisis dari stakeholder, efektivitas pelaksanaan program, hambatan, serta ajuan tindakan yang dapat 
dilakukan untuk optimalnya pelaksanaan program tersebut.

\section{Populasi dan Sampel}

Penelitian ini dilakukan di Kabupaten Garut, dengan sasaran populasi adalah seluruh Kepala Keluarga (KK) di Desa Padaawas, Kecamatan Pasir Wangi, Kabupaten Garut, yang berjumlah 1133 KK. Desa Padaawas dipilih sebagai populasi penelitian ini karena lokasi desa tersebut dekat dengan lokasi PT.Chevron, dan dianggap mendapat dampak yang paling signifikan dari pelaksanaan proyek community development dari PT.Chevron. Dari populasi tersebut diambil ukuran sampel yang berpedoman pada rumus Slovin dengan tingkat kelonggaran 15\% (Husen Umar, 1997) dan didapat 43 KK reponden. Cara pengambilan sampel digunakan teknik sampling proportionate random sampling dengan pembagian wilayah tiap RW secara proporsional di desa tersebut. Untuk keperluan analisis kajian ini, data atau informasi yang dikumpulkan berasal dari data hasil wawancara kepada pihak PT. Chevron, pihak Pemkab Garut dan pihak Masyarakat Desa Pasir Wangi. Untuk melengkapi kajian ini di lakukan pula penelusuran dari berbagai kebijakan atau dokumen maupun literatur yang terkait dengan kajian ini.

\section{Teknik Analisis Data}

Pada penelitian ini, digunakan teknik analisis deskripif yang didukung dengan tabulasi frekuensi data dan intepretasi pada pengkategorian garis interval. Variabel yang diteliti adalah pembangunan pada dimensi manusia, sosial, lingkungan hidup, dan ekonomi.

\section{PEMBAHASAN}

\section{Wujud Pelaksanaan Program Community Development Oleh PT.Chevron}

Bisnis PT. Chevron yang ada di Kabupaten Garut merupakan usaha di bidang pembangkit listrik tenaga panas bumi (PLTP) atau biasa dikenal dengan istilah geothermal, yang terwujud pada proyek kawah (pembangkit) darajat I, II, dan III. Pada dasarnya PT. Chevron ini merupakan perusahaan kontraktor atau mitra kerja sama dengan PT. Pertamina. Untuk penerapan tanggung jawab sosial di perusahaan secara internal sudah sesuai dengan standar operasional kerja dari PT.Chevron. Sedangkan untuk pelaksanaan program community development, perusahaan ini sudah mulai merinstis upaya ini sejak tahun 1994. Ada beberapa fokus bidang dari pelaksanaan program community development di tahun 2005, diantaranya adalah :

1. Bidang Pendidikan, diantaranya rehabilitasi gedung sekolah dasar (SD) Sukaraja III kecamatan Banyuresmi, donasi sarana pendidikan berupa furnitur kepada sekolah, bea-siswa untuk siswa berbakat dan dari kalangan berpendapatan rendah, lalu program pelatihan dan pengenalan lingkungan operasi panas bumi pada siswa.

2. Bidang Kesehatan, Pada bidang ini, kegiatan-kegiatan yang telah dilaksanakan adalah fasilitas penyediaan sarana air bersih, pembangunan "water box", dukungan kesehatan untuk ibu hamil, anak-anak yang kekurangan gizi, dan pengobatan gratis untuk komunitas berpendapatan rendah.

3. Bidang Pengembangan Ekonomi, Pada bidang ini, telah dilakukan dukungan untuk pengembangan usaha skala kecil pada peternakan bebek, pengembangbiakan kambing, peternakan lebah, serta usaha di bidang agricultural.

4. Bidang Infrastruktur, Pada bidang infrastruktur, ada beberapa program yang telah dilaksanakan adalah pembangunan jalan Sarimukti, lalu pembangunan sarana irigrasi Simajaya, serta renovasi gedung tempat peribadatan (mesjid).

5. Bidang Infrastruktur yang sedang berjalan (di tahun 2005), Pada bidang infrastruktur yang sedang berjalan, beberapa program yang sedang dilaksanakan adalah proyek hot mix jalan Tarogong - Panunjuk, lalu jalan utama Garut - Darajat, yang mana proyek ini telah dimulai pada tahun 2005 dan direncanakan selesai pada tahun 2006. 
Selain itu proyek yang dilakukan juga adalah renovasi gedung olahraga di Bale Paminton dan proyek "Chevron Landmark". Proyek ini dimulai pada bulan Januari tahun 2006, dan selesai pada bulan Mei tahun 2006.

Seluruh kegiatan ini menghabiskan anggaran sebesar 753.050 US Dolar, dengan alokasi terbesar pada pembangunan infrastruktur dengan 52\%.

\section{Efektivitas Pelaksanaan Program} Community Development Oleh PT.Chevron

Pengukuran efektivitas pelaksanaan program community development, penelitian ini menggunakan indikator-indikator dari tujuan ideal dari program community development dan corporate social responsibility, yaitu tercapainya pembangunan yang berkesinambungan pada dimensi manusia, sosial, lingkungan hidup, dan ekonomi.

1. Dimensi Manusia, jumlah frekuensi yang terbanyak dari dimensi ini adalah jawaban "ragu-ragu" yaitu sebesar 38\% dari seluruh responden. Berdasarkan wawancara pada warga didapat bahwa bantuan bea siswa, renovasi gedung sekolah $\mathrm{SD}$, dan sarana kesehatan masih dirasa kurang meluas manfaatnya. Sedangkan dukungan perusahaan terhadap kegiatan keagamaan masyarakat dirasa cukup.

2. Dimensi Sosial, jumlah frekuensi yang terbanyak dari dimensi ini adalah jawaban "ragu-ragu" dan "tidak setuju" yaitu sebesar $36 \%$ dari seluruh responden. Dikaitkan dengan hasil wawancara dengan warga, didapat informasi bahwa perusahaan belum memfasilitasi akses kerja sama pihak warga dengan pihak lain. Dukungan yang selama ini perusahaan berikan berupa partisipasi dana ke dalam kegiatan-kegiatan yang melibatkan orang banyak, seperti perayaan hari-hari besar.

3. Dimensi Lingkungan Hidup, jumlah frekuensi yang terbanyak dari dimensi ini adalah jawaban "tidak setuju" yaitu sebesar $29 \%$, dan terbanyak kedua adalah jawaban "setuju" dengan jumlah $26 \%$ dari seluruh responden. Hasil yang bervariasi ini sejalan dengan pendapat para warga yang meskipun mereka mengaku merasakan banyak manfaat dari pembangunan infrastruktur di lingkungannya, tapi mereka juga merasa terganggu dengan lalu-lalang kendaraan besar dari operasional PT.Chevron.

4. Dimensi Ekonomi, jumlah frekuensi yang terbanyak dari dimensi ini adalah jawaban "ragu-ragu" dan "tidak setuju" yaitu sebesar $48 \%$ dari seluruh responden. Dari hasil wawancara dengan beberapa warga diketahui bahwa meskipun perusahaan pernah memfasilitasi pelatihan keterampilan usaha (contoh: peternakan, menjahit, dsb), tetapi karena tidak ada akses modal dan pemasarannya, mereka belum merasakan manfaat yang optimal dari program ini.

5. Akumulasi Dari Efektivitas DimensiDimensi Dari Community Development, setelah mengetahui jumlah skor dari masing-masing dimensi efektivitas pelaksanaan program community development ini, kemudian akan dilakukan pengakumulasian jumlah skor keseluruhan beserta intepretasi kategorinya pada garis interval. Hasil perhitungan menunjukkan bahwa jumlah akumulasi skor dari seluruh dimensi adalah 1301 yang bila diintrepetasikan pada garis interval, jumlah skor tersebut berada pada kategori "tidak baik". Hal ini menunjukkan bahwa meskipun pada pelaksanaannya, program community development dari PT. Chevron ini menghabiskan dana yang cukup banyak, tetapi kebermanfaatannya terhadap stakeholder masih kurang dirasakan oleh warga desa, khususnya desa Padaawas, Kecamatan Pasir wangi, Kabupaten Garut. Kurang efektifnya pelaksanaan program ini yang didasarkan jawaban sampel responden dari 43 Kepala Keluarga di Desa Padaawas ini, bisa jadi karena kurang tersosialisasikan dengan baik seluruh program-program community development yang dilaksanakan oleh PT.Chevron kepada warga desa Padaawas. 
Selain itu, luasnya wilayah kerja dari penerapan program ini (level Kab.Garut), menyebabkan pengaruh dari program yang dirasakan oleh warga desa Padaawas tidak terlalu signifikan.

\section{Hambatan-Hambatan Dari Pelaksanaan Program Community Development Oleh PT.Chevron}

Berdasarkan wawancara dengan personel PT.Chevron pada bagian community relations ini mengemukakan beberapa hambatan yang dialami perusahaan dalam melaksanakan program ini sebagai berikut :

1. Tekanan dari berbagai pihak, baik itu pihak masyarakat maupun pihak pemerintah, yang menuntut pihak PT.Chevron untuk selalu berkontribusi lebih atas bagi hasil dari laba hasil operasional perusahaan. Hal ini secara psikologis, dapat menambah beban kerja mereka.

2. Pola program community development yang selama ini diterapkan, adalah PT.Chevron berupaya mengakomodir usulan-usulan program yang masuk dari pihak desa, kecamatan, maupun Bappeda. Hanya saja, dari usulan tersebut, pihak PT.Chevron merasa banyak usulan program yang tidak sesuai dengan program/rambu community development yang akan diterapkan oleh perusahaan.

3. Mindset (pola pikir) masyarakat desa yang pada umumnya masih mengharapkan manfaat jangka panjang dari bantuan berupa pembangunan sarana fisik di daerahnya dari PT. Chevron.

\section{Cara Mengatasi Hambatan-Hambatan Pelaksanaan Program Community Development Oleh PT.Chevron}

Adapun upaya-upaya yang akan dilakukan oleh PT.Chevron dalam mengatasi berbagai hambatan dari pelaksanaan program adalah sebagai berikut :

1. Pihak perusahaan akan mencoba merubah pola pelaksanaan program community development ini, agar lebih bersifat proaktif. Artinya secara aktif akan meneliti kebutuhan masyarakat, merancang program yang sesuai, serta melibatkan para stakeholder dalam pelaksanaannya.

2. Dalam pelaksanaannya pihak PT.Chevron akan melibatkan pihak-pihak yang kompenten, baik dari lokal maupun dari luar daerah, untuk mendukung program commnunity development ini berjalan optimal.

3. Mencoba merubah secara bertahap, alokasi utama dari pelaksanaan program ini bukan lagi di bidang pembangunan fisik dari struktur-infrastruktur tetapi lebih pada bidang pendidikan. Karena bidang pendidikan dinilai akan lebih memberi manfaat kepada masyarakat desa untuk jangka yang lebih panjang dan berkelanjutan.

4. Agar pemanfaatan program dapat dirasakan lebih optimal, PT. Chevron juga akan lebih memperhatikan pembangunan masyarakatnya pada wilayah yang terdekat dari lokasi operasional perusahaan.

\section{KESIMPULAN DAN SARAN Kesimpulan}

Berdasarkan hasil penelitian dan pembahasan mengenai efektivitas pelaksanaan program community development oleh PT. Chevron di Kabupaten Garut ini, maka dapat diambil beberapa kesimpulan sebagai berikut :

1. Program Corporate Social Responsibility secara internal, PT. Chevron telah menerapkan standar manajemen operasional yang berkualitas sekaligus memelihara kelestarian sosial, kesehatan, keamanan dan lingkungan hidup sekitarnya. Sedangkan untuk programprogram community development yang telah dilaksanakan oleh PT. Chevron di Kabupaten Garut pada tahun 2005, berlandaskan pada beberapa bidang, yakni: bidang pendidikan, bidang kesehatan, bidang sosial ekonomi dan bidang infrastrutur, serta sumbangan-sumbangan lainnya, dengan alokasi terbesar adalah pada bidang infrastruktur yakni sebesar $52 \%$.

2. Pengukuran tingkat efektivitas dari pelaksanaan program community 
development oleh PT. Chevron, dengan mengambil sampel masyarakat pada Desa Padawaas, Kecamatan Pasir wangi, Kabupaten Garut ini, menghasilkan jumlah skor 1301 yang bila diintepretasikan pada garis interval, jumlah tersebut berada pada kategori "tidak baik". Hal ini menunjukkan bahwa pelaksanaan program community development oleh PT.Chevron pada masyarakat desa ini berjalan kurang efektif. Dari hasil observasi dan penelitian juga didapat informasi adanya beberapa faktor yang belum berjalan secara optimal, diantaranya adalah faktor sosialisasi dan komunikasi, lalu faktor kesehatan, serta faktor bantuan akses kerjasama sosial dan ekonomi, diharapkan untuk lebih mendapat perhatian dari perusahaan. Meskipun demikian masyarakat desa juga telah merasakan manfaat dari program community development ini berupa pembangunan fisik sarana-prasarana seperti pembangunan jalan, renovasi mesjid, fasilitas air bersih, toilet umum, dan lain sebagainya.

3. Hambatan-hambatan yang dirasakan oleh PT.Chevron diantaranya adalah adanya tuntutan yang berlebih dari berbagai pihak mengenai bantuan program community development ini yang setidaknya hal tersebut dapat menambah beban kerja dari para pelaksana program tersebut, lalu pengajuan program yang kurang sesuai dengan konteks program community development, dan sulitnya merubah mindset (kerangka pikir) dari masyarakat yang lebih mengharapkan bantuan untuk kepentingan jangka pendek.

4. Sedangkan Upaya-upaya yang sedang dan akan dilakukan oleh PT.Chevron dalam mengatasi hambatan tersebut adalah dengan cara menyusun pola baru dari pelaksanaan program community development agar lebih bersifat proaktif, lalu mulai melibatkan pihak-pihak yang berkompeten, baik itu dari potensi lokal mampun luar daerah, serta lebih memperhatikan pembangunan pada masyarakat di wilayah sekitar lokasi operasi perusahaan agar dampak dari program dapat dirasakan lebih optimal.

\section{Saran}

Terkait kesimpulan yang didapat, peneliti mengajukan beberapa saran kepada pihak pelaksana di bidang teliti ini, agar pelaksanaan program community development dapat terlaksana lebih optimal. Adapun saran-saran yang dimaksud adalah sebagai berikut :

1. Untuk meningkatkan sarana komunikasi dan sosialisasi program pada masyarakat maupun Bappeda. Dengan selalu mensosialiasikan program, setidaknya pihak Bappeda dapat melanjutkan dan memelihara hasil pembangunan yang telah dirintis perusahaan. Selain itu kan terbentuk citra baik di masyarakat luas yang pada akhirnya akan memberi manfaat pada perusahaan juga.

2. Untuk mendukung pola baru yang akan dilaksanakan, sifat proaktif dari perusahaan dapat dimulai dari suatu acara pertemuan dari para perwakilan stakeholder (pihak masyarakat, kecamatan, dan Bappeda) yang PT.Chevron sebagai inisiator dan tuan rumahnya.

3. Rencana pelibatan pihak-pihak yang berkompeten dalam mendukung pelaksanaan program ini adalah rencana yang bagus. Tetapi ada hal yang perlu diperhatikan dalam pelaksanaannya, yaitu tidak semua pihak yang dirasa mempunyai kompeten bagus itu mempunyai cara / metode penanganan yang sesuai dengan kultur maupun budaya masyarakat di daerah pedesaan.

4. Perlu penanganan yang menyeluruh agar manfaat program dapat dirasakan optimal. Semisal program pengembangan ekonomi, tentang pelatihan keterampilan berwirausaha, perlu dicarikan pula bagaimana para peserta program dalam mengakses modal dan jalur pemasarannya.

5. Terkait rencana akan lebih fokusnya perhatian pelaksanaan program pada wilayah sekitar operasi perusahaan, adalah perlu dirancangkan suatu program yang melibatkan perwakilan dari masing- 
masing kecamatan, yang berorientasi meningkatkan kapasitas dan kemandirian, yang berdampak pada perwakilan tersebut dapat membangun kecamatannya masingmasing.

\section{Daftar Pustaka}

Arif Budimata, dkk. 2004. Corporate Social Responsibility Jawaban bagi Model Pembangunan Indonesia Masa Kini. Jakarta: Indonesia Center for Sunstainable Development (ICSD).

Bambang Rudito. 2004. Corporate Social Resposibility. Cetakan Pertama. Jakarta: ICSD.

Ife, Jim. 1995.Community Development: Creating Community Alternatives-Vision, Analysis and Practice. Addison Wesley Longman Australia Pty Limited.

Husen Umar. 1997. Metode Riset Ilmu Administrasi. Jakarta : Gramedia.

Masri Singarimbun. 1989. Metode Penelitian Survey. Cetakan Pertama. Jakarta: LP3S.

Soewarno Handayaningrat, 1988. Pengantar Studi Ilmu Administrasi dan Manajemen. Jakarta : CV. Haji Masagung. 